\title{
Monitoring Shoshonea pulvinata in the Pryor and Beartooth Mountains, Carbon County, Montana 1999 Trend Report
}

Prepared for:

\author{
Bureau of Land Management \\ Billings Field Office \\ 810 East Main \\ Billings, MT 59105-3395
}

Prepared by:

Bonnie Heidel

June2001

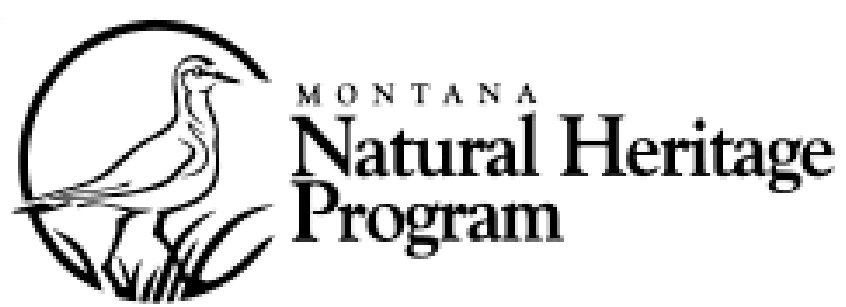




\section{Monitoring Shoshonea pulvinata in the Pryor and Beartooth Mountains, Carbon County, Montana 1999 Trend Report}

\section{(C) 2001 Montana Natural Heritage Program}

State Library Building • P.O. Box 201800 1515 East Sixth Avenue • Helena, MT 59620-1800 406-444-3009

This document should be cited as follows:

Heidel, B. 2001. Monitoring Shoshonea pulvinata in the Pryor and Beartooth Mountains, Carbon County, MT. 1999 trend report to Bureau of Land Management, MT. Montana Natural Heritage Program, Helena. 11 pp. plus appendices. 


\section{Executive Summary}

Shoshonea pulvinata represents a monotypic genus that is endemic to the Beartooth and Pryor mountain ranges of Carbon County, Montana and the Absaroka and Owl Creek ranges of Park and Fremont counties, Wyoming (Lesica and Shelly 1988, Fertig et al. 1994 ). The species is ranked as G2G3/S1 (globally imperiled or vulnerable, critically imperiled in the state) by the Montana Natural Heritage Program. It is recognized as sensitive by the Montana State Office of the Bureau of Land Management (USDI BLM 1996).

Demographic monitoring was repeated at 3 permanent belt transects in 1999 following an annual baseline monitoring in 1991-1993 to evaluate the stability of Shoshonea pulvinata numbers and its status as a sensitive plant species. In the original monitoring survey the species appeared to be stable, however, potential threats and impacts to existing populations were identified. In this study we determined changes in the numbers of individuals by size and reproductive characteristics within the sample plots, tracking individual plants between years, in order to determine speciesírates of growth, fecundity, recruitment and mortality. As a result, we found less difference between mortality and recruitment in the 1993-1999 interval as compared with differences between earlier annual monitoring intervals. This further documents the relative stability of the species in a range of settings, and its long-lived nature.

Growth rates were calculated to characterize trend. The Grove Creek transect had the highest growth rate values and is the sample set with the highest densities and highest proportion of small, possibly young plants. The Mystery Cave Ridge Transect had the lowest growth rate, and is the sample set with the lowest densities and high proportion of large, possibly old plants. Preliminary interpretations are offered for these opposite trends subject to testing in the course of management planning and assessment. 


\section{Acknowledgements}

The interest and support of Don Heinze, Jay Parks and Sandy Brooks (Bureau of Land Management) is greatly appreciated. The establishment of monitoring plots and coordination of all previous years of monitoring between 1991-1993 was the work of Peter Lesica. Editing assistance was provided by Joy Lewis (Montana Natural Heritage Program) and layout assistance was provided by Katrina Scheuerman (Natural Resources Information Service.)

This project was supported by a challenge cost-share agreement between the Bureau of Land Management and the Montana Natural Heritage Program. 


\section{Table of Contents}

Introduction

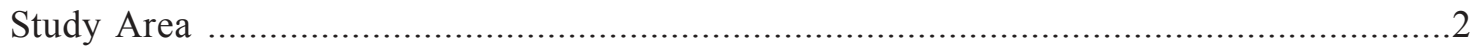

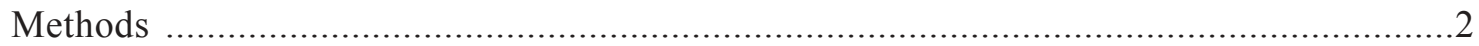

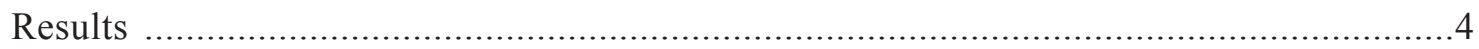

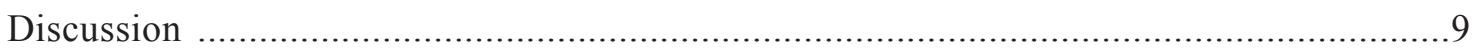

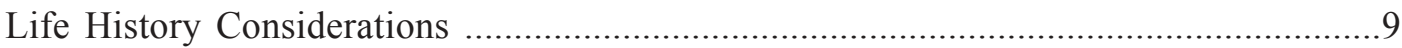

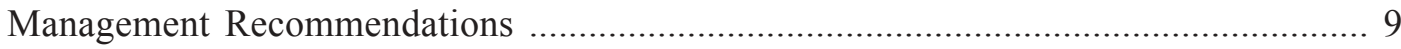

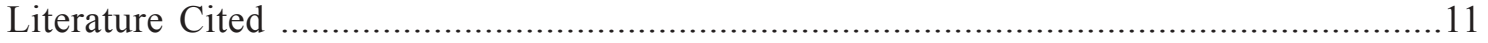

Tables and Figures

Table 1. The settings of Shoshonea pulvinata monitoring transects ....................................2

Table 2. Summary statistics for Shoshonea pulvinata at three monitoring sites in 1991-1999... 4

Table 3. Mean annual recruitment and mortality numbers of Shoshonea pulvinata .................6

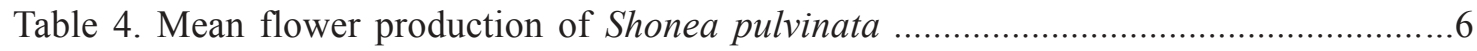

Table 5. Measures of viability based on growth rate and elasticity .......................................6

Table 6. Tally of Shoshonea pulvinata plant size changes .................................................

Table 7. Measures of plant surface area trends based on growth rate and elasticity..................7

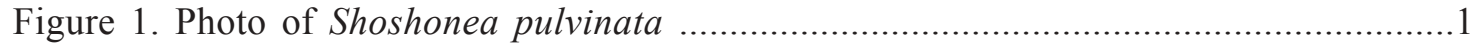

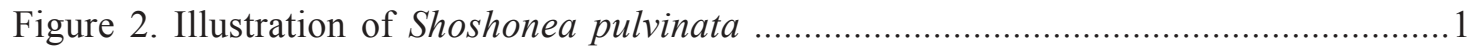

Figure 3. Shoshonea pulvinata at Grove Creek transect ñ total numbers ............................5

Figure 4. Shoshonea pulvinata at Mystery Cave Ridge transect ñ total numbers ..................5

Figure 5. Shoshonea pulvinata at Mystery Cave Road transect ñ total numbers ....................5

Figure 6. Shoshonea pulvinata at Grove Creek transect ñ total surface area ......................8

Figure 7. Shoshonea pulvinata at Mystery Cave Ridge transect ñ total surface area ............8

Figure 8. Shoshonea pulvinata at Mystery Cave Road transect $\tilde{n}$ total surface area ..............8

Appendices

Appendix A. Study area photographs

Appendix B. Climate of Lovell, Wyoming

Appendix C. Mean monthly precipitation and temperature in Lovell, Wyoming

Appendix D. Shoshonea pulvinata raw monitoring data

Appendix E. Global and State Ranking Guidelines 


\section{Introduction}

Shoshonea pulvinata Evert \& Constance is a long-lived, mat-forming perennial in the Carrot Family This recently described species (Evert and Constance 1982) represents a monotypic genus that is endemic to the Beartooth and Pryor mountain ranges of Carbon County, Montana and the Absaroka and Owl Creek ranges of Park and Fremont counties, Wyoming (Lesica and Shelly 1988, Fertig et al. 1994). In Montana, Shoshonea pulvinata is generally restricted to shallow, calcareous soils of exposed limestone outcrops, rims, ridgetops and talus slopes at 6,800-7,800 ft (Lesica and Shelly 1988). The species is ranked as G2G3/S1 (globally imperiled or vulnerable, critically imperiled in the state) by the Montana Natural Heritage Program. It is recognized as sensitive by the Montana State Office of the Bureau of Land Management (USDI BLM 1996). It was a former candidate for listing as a threatened or endangered species by the U.S. Fish and Wildlife Service (USDI FWS 1993) until dropped as a candidate in 1996 with the elimination of the candidate program.

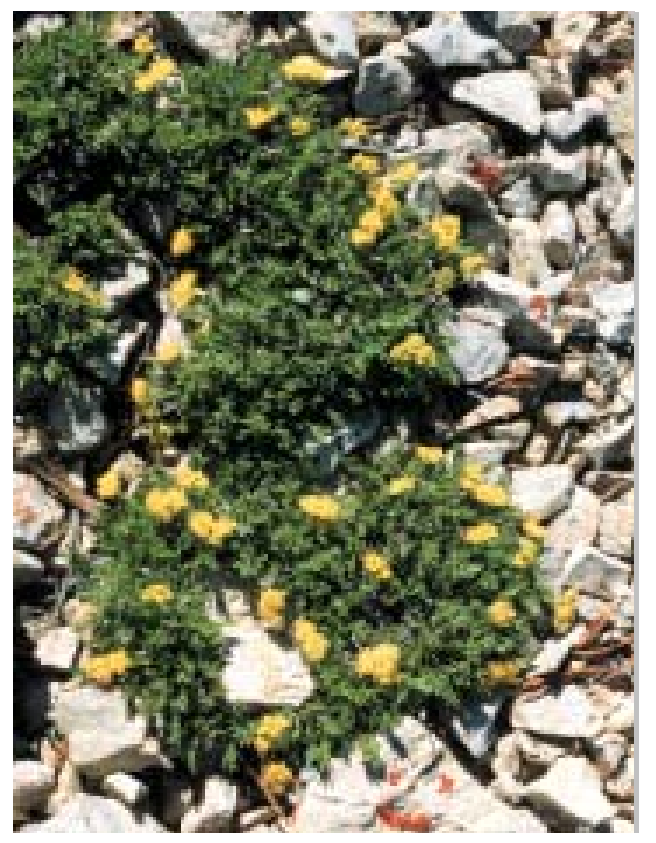

Figure 1. Photo of Shoshonea pulvinata by Peter Lesica
Montana botanists initiated demographic monitoring of Shoshonea pulvinata in 1991 to learn about the speciesístatus and stability, including growth, fecundity, recruitment and mortality rates. All known populations of Shoshonea pulvinata in Montana appeared to be stable at the time of the status survey (Lesica and Shelly 1988). However, potential threats and impacts to the species were identified, including oil, gas, and mining developments in the Beartooth Mountains, and grazing of wild horses and bighorn sheep in the Pryor Mountains (Lesica 1993). Three permanent monitoring transects were established in 1991 (Lesica and Achuff 1991). Mapped individuals were followed for 2 consecutive years. The preliminary analysis indicated that the sample populations were stable (Lesica 1992, 1993). Mortality and recruitment were characterized as low and episodic. The change in plant size as an indication of vigor did not change significantly over time. The author recommended that the plots be periodically reread to check for major changes in trend. The plots were re-read in 1999, and this report represents a review of trends, with expanded information on life history parameters.
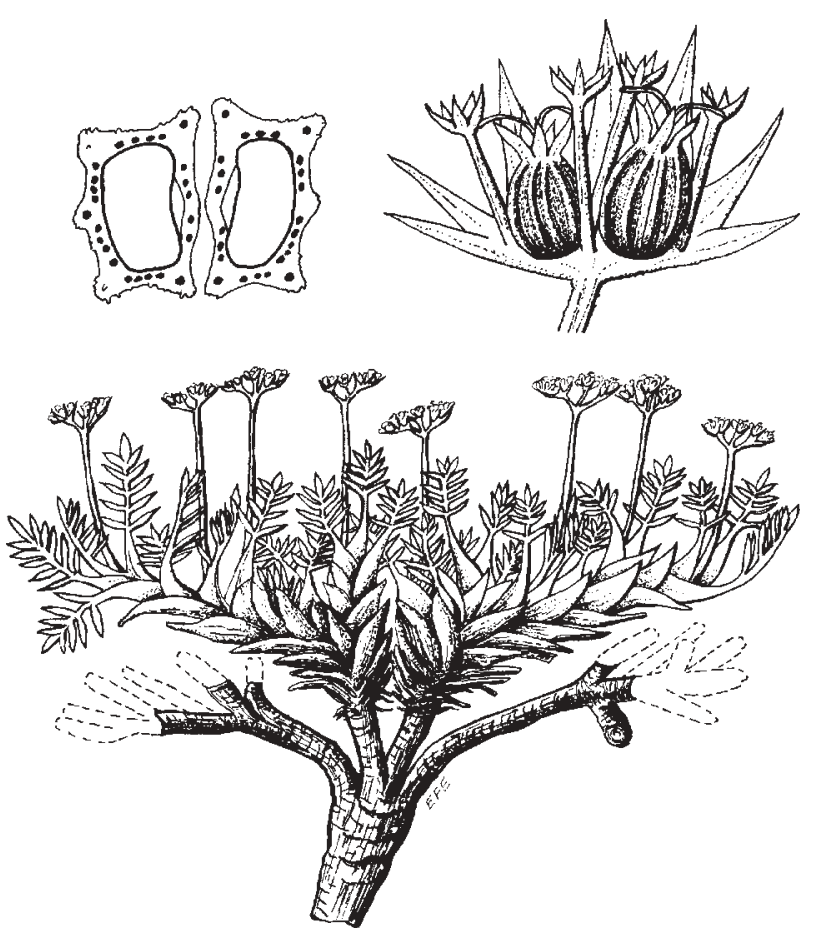

Figure 2. Illustration of Shoshonea pulvinata 


\section{Study Areas}

Permanent belt transects were established in 2 of the 4 known populations of the species in Montana. One belt transect was established in the largest Montana population of Shoshonea pulvinata, Grove Creek, on the east slopes of the Beartooth Mountains. Two permanent belt transects were established in a large Montana population of Shoshonea pulvinata at the east end of the Pryor Mountains near Mystery Cave. The 2 transects are referred to as Mystery Cave Ridge and Mystery Cave Road transects. They are within the newly-designated East Pryor Mountains Area of Critical Environmental Concern (ACEC). Locations of transects are detailed in Lesica and Achuff(1991) with annotations in Lesica (1993).

The transects encompass relatively high densities of Shoshonea pulvinata in a range of microhabitats. The settings of the transects are briefly characterized below (Table 1). A photograph of the transect at the Mystery Cave Road transect is shown in Appendix A, accompanied by photo- graphs of the Mystery Cave Ridge transect setting and the Grove Creek transect setting. The species occupies lower montane ridges that rise above cold desert. Meteorological data from the nearest monitoring station at Lovell, Wyoming represents the cold desert climate. It has mean annual rainfall of $17.0 \mathrm{~cm}$ (6.7 in.) that varies greatly within and between years, and mean annual temperatures that contribute to drought conditions throughout most of the growing season (Appendix B; from NOAA records, 1948-1999). While the temperature and rainfall values of montane settings are typically moderated by elevation, the arid habitats of Shoshonea pulvinata are located on exposed, montane ridges.

Monthly rainfall totals and mean monthly temperature values are presented over 19901999, including the year prior to initial monitoring, to show the range of climate conditions from the nearest meterological station at Lovell, WY (Appendix C.) The lowest annual precipitation year was 1999 with a total 4.08 inches; other low precipitation years below the mean were in 1990 and 1994.

\begin{tabular}{|l|l|c|c|l|}
\hline \multicolumn{5}{|c|}{ Table 1. The settings of Shoshonea pulvinata monitoring transects } \\
\hline Transect & Aspect & $\begin{array}{c}\text { Slope (est. } \\
\text { \%) }\end{array}$ & $\begin{array}{c}\text { Tree canopy } \\
\text { cover (est. \%) }\end{array}$ & Description \\
\hline \hline Grove Creek & Northwest & 5 & 5 & $\begin{array}{l}\text { Very open limber pine woodland, on } \\
\text { limestone pavement }\end{array}$ \\
\hline Mystery Cave Ridge & Southwest & 1 & 1 & $\begin{array}{l}\text { Exposed rim outcrop adjoining forest, on } \\
\text { limestone pavement }\end{array}$ \\
\hline Mystery Cave Road & West & 1 & 35 & $\begin{array}{l}\text { Open Douglas-fir forest, on limestone } \\
\text { covered by duff }\end{array}$ \\
\hline
\end{tabular}

\section{Methods}

Our goal was to detect all changes in the numbers of individuals by size and reproductive characteristics within the sample plots, tracking individual plants between years, in order to determine speciesírates of growth, fecundity, recruitment and mortality. We followed a total of 161 individu- als between 1991-1993 and revisited them 6 years later to check for major trend changes.

In the particular case of long-lived perennials, demographic monitoring has far greater value than census techniques because noticeable changes usually occur slowly, and important 
growth-limiting population-level events may be infrequent. Demographic monitoring of growth, fecundity, recruitment and mortality are essential to understand the condition and trends of plant populations, particularly longlived, slow-growing species. The extra time required for demographic monitoring is a modest trade-off in return for the great amount of additional life history information and basis for analysis.

For optimal sample sizes in demographic monitoring, permanent $10-\mathrm{m}$ belt transects of 0.5 -m width were placed in areas of relatively high density of Shoshonea pulvinata plants. This procedure is described in the original establishment report (Lesica and Achuff 1991), consistent with Lesica (1987). The monitoring was designed to track individuals over time for comparison within transects, rather than between transects. Each transect contained fewer than 100 plants, and this sample set signified between 1-3\% of estimated population numbers in the Grove Creek transect and combined in the Mystery Cave transects, respectively.

Study site locations are detailed in Achuff and Lesica (1991) with annotations in Lesica (1993). Monitoring was conducted during or after flowering, generally between June 16-29, except for the establishment date of the Grove Creek transect on 29 July, and the delay until August in reading transects in 1999. The leaf petioles elongate slightly over the summer, so that an August reading might give different surface area estimates. We estimated surface area conservatively for this reason. The timing of the survey in 1999 was beneficial because it provided data on the seedling stage, which is discussed in this report but not incorporated in analysis because all previous monitoring took place before seedlings emerged.

At every transect, each Shoshonea pulvinata plant is assigned a unique alpha-numeric code that identifies it. If the plant occurred in the first meter of the belt transect, it is given the code ì1 followed by a letter assigned in order. In 1991 there were 6 plants recorded in the first 1 meter of the Grove Creek transect. We assigned these 6 plants the following codes 1a, 1b, 1c, 1d, $1 \mathrm{e}$ and $1 \mathrm{f}$ (Appendix D). These unique codes remain assigned to the plant at that location for the duration of the study. If a new plant appears in the first meter of this belt transect in subsequent years, it will be assigned the code $1 \mathrm{~g}$ etc. Assigning a unique alpha-numeric code to each plant allows us to easily follow the fate of individuals during the coarse of the study.

After the coordinates of each plant have been recorded, its size is estimated using a $50 \mathrm{~cm}$ X 50 $\mathrm{cm}$ sheet of clear plexiglass marked into a grid of squares that are $4 \mathrm{~cm} \mathrm{X} 4 \mathrm{~cm}$ each. The grid is placed on top of each Shoshonea pulvinata plant in a random orientation and the number of 1/4squares that are filled by green vegetation is counted (Fig. 3). For each plant, we counted the number of 1/4-squares and multiplied the total by 4. This gives the area of the foliage in squarecentimeters. Many larger plants have died out in the center; this dead region is not counted. Finally, for each plant, the number of inflorescences is counted. This procedure is repeated for every Shoshonea pulvinata plant in the 50 -cm wide belt transect defined by the tape. Each plantís size and reproductive status can now be summarized using the following codes:

$$
\begin{aligned}
& \text { A (area)= area of vegetation in square- } \\
& \mathrm{cm} \\
& \text { I (inflorescences) = number of inflores- } \\
& \text { cences }
\end{aligned}
$$

Thus, a plant with an area of 6 1/4-squares and 3 inflorescences is coded, A24-I3. In addition, seedlings were recorded (A0) and mapped in 1999.

The single-stalk plants consistently fell within the smallest category, the ìA4î category measuring less than or equal to $4 \mathrm{~cm} \leq$. This is ultimately the 
only size category that was not found in flower, though flowering was rare in plants less than 16 $\mathrm{cm} \leq$.All plants of $16 \mathrm{~cm} \leq$ or less were referred to as juvenile plants in previous reports on this study, but this name can be misleading. There were plants that remained in the ìA4î category throughout the entire nine-year monitoring timespan. We now refer to the iA4î as the smallest class without reference to age, and distinguished it from flowering and nonflowering plants. The largest plant documented was 2,272 $\mathrm{cm} \leq$ at the Mystery Cave Ridge in 1999. We otherwise split and tallied the results in the original categories of Lesica (1992):

(1) Smallest plants, area of $15 \mathrm{~cm} \leq$ or less

(2) Small mature, area of $16-80 \mathrm{~cm} \leq$

(3) Large mature, area of $>80 \mathrm{~cm} \leq$

In comparing the size values between years, we scored all changes as net increases or decreases if values differed between years for plants less than $16 \mathrm{~cm} \leq$. Size estimate consistency diminishes with size and we did not score values as changing if they were no more than $4 \mathrm{~cm} \leq$ difference between years for plants larger than $16 \mathrm{~cm} \leq$.

Originally, a t-test and Wilcoxonís sign tests were used with data representing tallies of the number of plants which had increased, decreased or remained with the same surface area (Lesica 1993).
A g-test (Sokal and Rohlf 1981) was substituted for the former as a more robust test of significance.

We graphed trends in plant numbers and in plant sizes to provide an overview of gross changes. The tallies distinguished between the smallest size category plants and larger flowering or nonflowering plants. Then we calculated the linear regression of values over time. Monitoring was originally set up for stagebased monitoring, but the sample sizes were small for running projections. Instead, we calculated the estimated elasticity parameter to determine how quickly the mean changes, and the estimated growth rate parameter to determine how quickly the variance in the normal distribution changes (Dennis et al. 1991). These were calculated using the Excel Toolkit regression analysis, and forcing the regression line to have a y-intercept of zero.

\section{Results}

The numbers of plants in sample populations has been stable at Grove Creek and Mystery Road. Sample populations declined appreciably at Mystery Ridge in 1991-92 but were stable in 1992-93. The net changes in number

\begin{tabular}{|l|c|c|c|c|c|c|c|c|c|c|c|c|}
\hline \multicolumn{9}{|c|}{ Table 2. Summary statis tics for Shoshonea pulvinata at three monitoring sites in 1991-1999 ${ }^{\mathbf{1}}$. } \\
\hline & \multicolumn{3}{|c|}{ Grove Creek } & \multicolumn{3}{c|}{ Mystery Cave Ridge } & \multicolumn{3}{c|}{ Mys tery Cave Road } \\
\hline & $\mathbf{1 9 9 1}$ & $\mathbf{1 9 9 2}$ & $\mathbf{1 9 9 3}$ & $\mathbf{1 9 9 9}$ & $\mathbf{1 9 9 1}$ & $\mathbf{1 9 9 2}$ & $\mathbf{1 9 9 3}$ & $\mathbf{1 9 9 9}$ & $\mathbf{1 9 9 1}$ & $\mathbf{1 9 9 2}$ & $\mathbf{1 9 9 3}$ & $\mathbf{1 9 9 9}$ \\
\hline \hline Total es tablished plants & 57 & 68 & 66 & 67 & 32 & 23 & 22 & 19 & 50 & 47 & 47 & 45 \\
\hline Mature plants & 28 & 26 & 29 & 33 & 31 & 19 & 19 & 16 & 44 & 1 & 38 & 41 \\
\hline Reproductive plants & 16 & 11 & 15 & 29 & 21 & 12 & 16 & 14 & 30 & 14 & 30 & 26 \\
\hline Reproductive rate & $57 \%$ & $42 \%$ & $52 \%$ & $87 \%$ & $71 \%$ & $65 \%$ & $84 \%$ & $87 \%$ & $68 \%$ & $37 \%$ & $79 \%$ & $51 \%$ \\
\hline Seedlings & -- & -- & -- & 13 & -- & -- & -- & -- & -- & -- & -- & 11 \\
\hline Mortality & -- & 3 & 7 & 4 & -- & 10 & 2 & 3 & -- & 4 & 1 & 4 \\
\hline Mortality rate & -- & $5 \%$ & $10 \%$ & $6 \%$ & -- & $30 \%$ & $9 \%$ & $14 \%$ & -- & $8 \%$ & $2 \%$ & $9 \%$ \\
\hline Recruitment & -- & 14 & 5 & 5 & -- & 1 & 1 & 0 & -- & 1 & 1 & 2 \\
\hline Recruitment rate & -- & $25 \%$ & $7 \%$ & $8 \%$ & -- & $3 \%$ & $4 \%$ & 0 & -- & $2 \%$ & $2 \%$ & $4 \%$ \\
\hline
\end{tabular}

\footnotetext{
${ }^{1}$ Reproductive rate is the number of plants producing inflorescences/number of mature plants. Mortality rat is the number of dead plants in year $t /$ number of plants in year $t-1$. Recruitment rate is the number of new plants in year $\mathrm{t} /$ number of plants in year $\mathrm{t}-1$.
} 


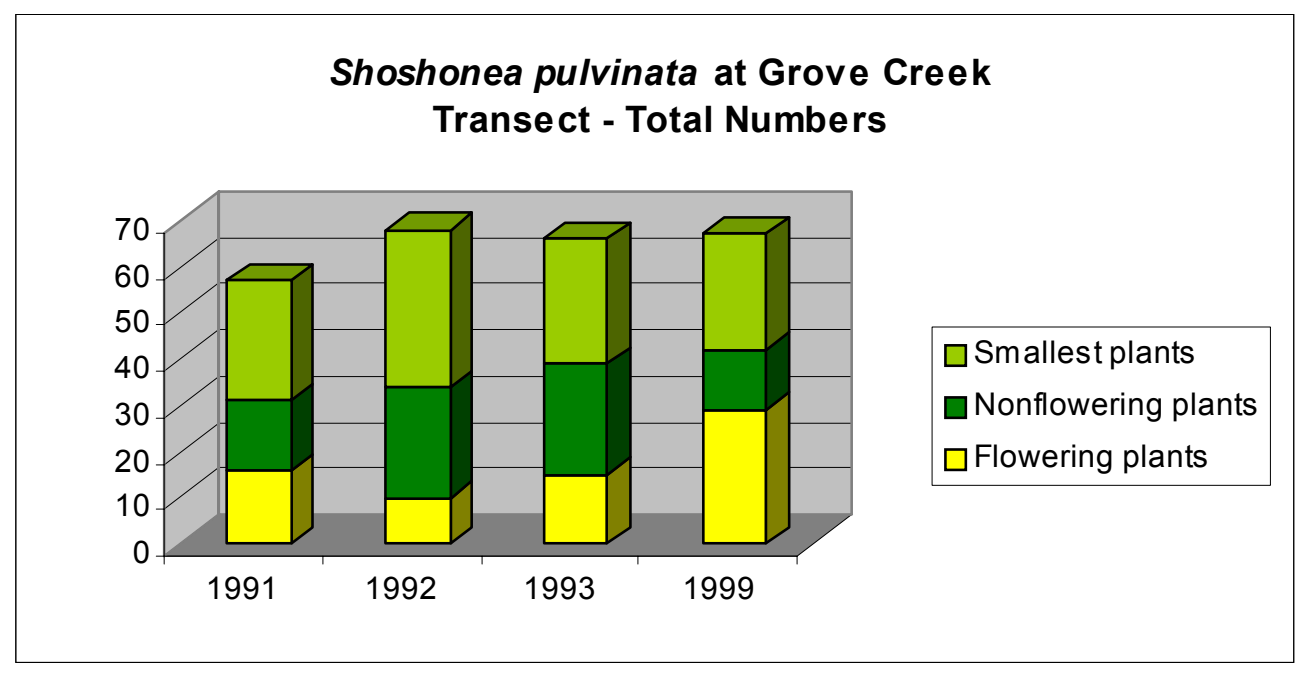

Figure 3

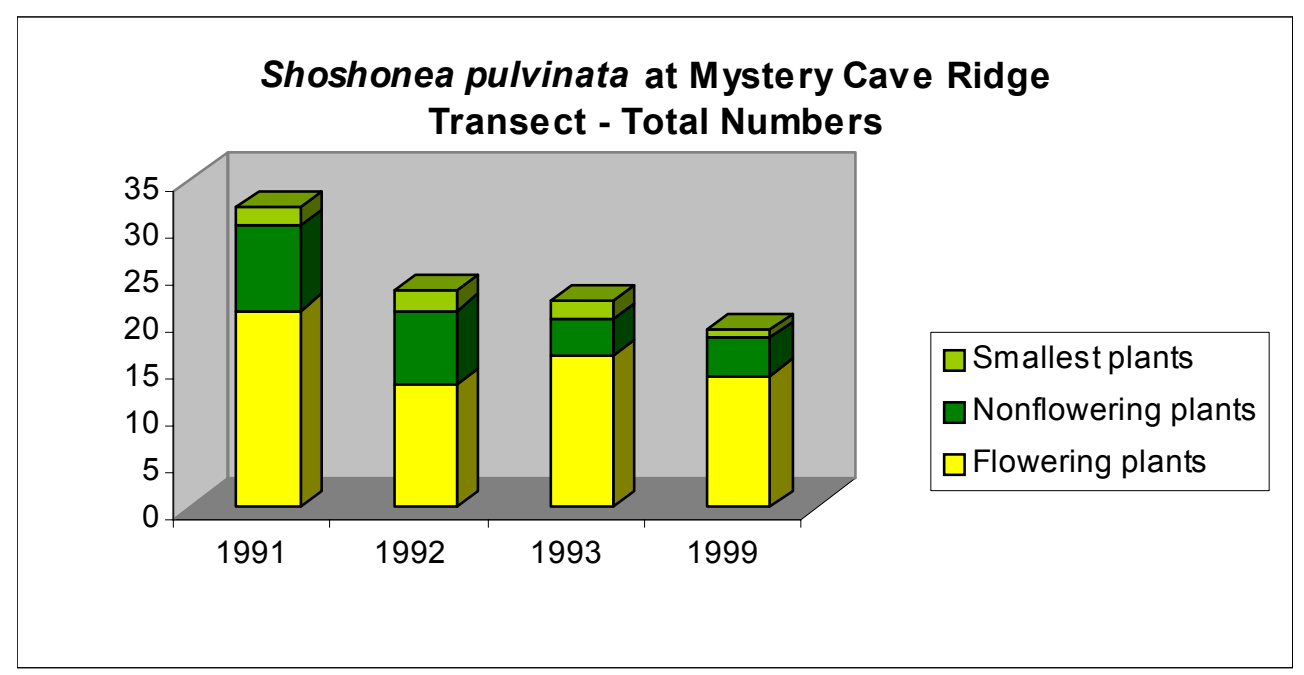

Figure 4

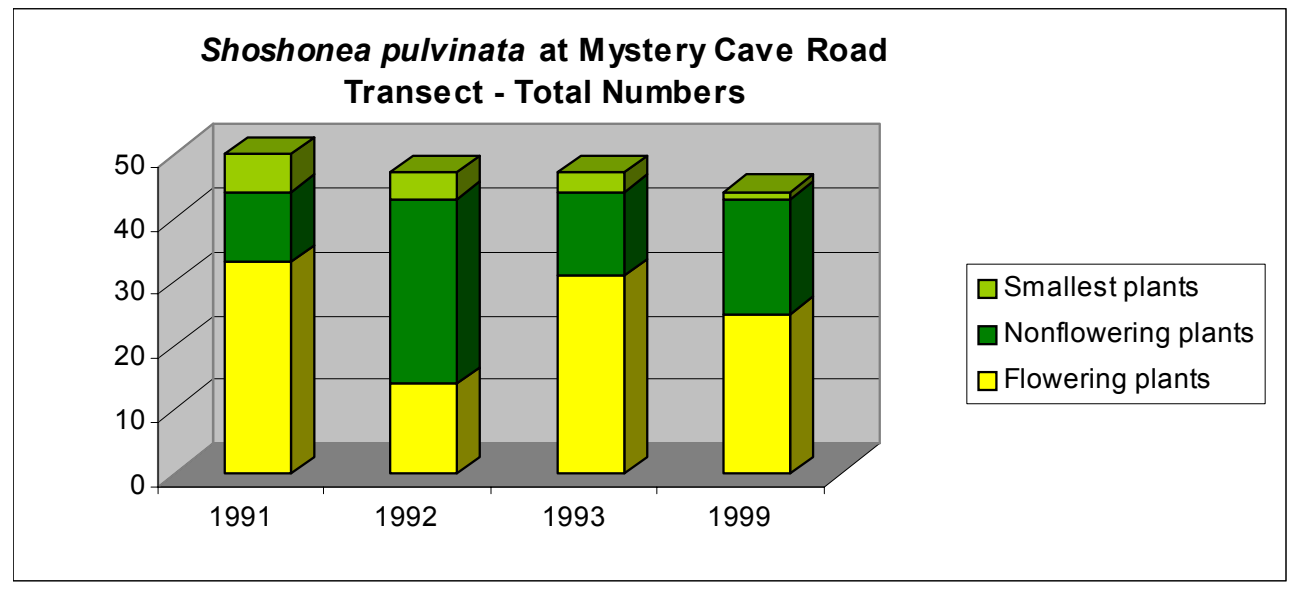

Figure 5 


\begin{tabular}{|l|c|c|c|}
\hline $\begin{array}{l}\text { Table 3. Mean annual recruitment and mortality numbers of } \\
\text { Shoshonea pulvinata }\end{array}$ \\
\hline & \multicolumn{3}{|c|}{ Mean annual no. of plants } \\
\hline & Grove Creek & $\begin{array}{c}\text { Mys tery Cave } \\
\text { Ridge }\end{array}$ & $\begin{array}{c}\text { Mystery Cave } \\
\text { Road }\end{array}$ \\
\hline \hline Recruitment & 8.00 & 0.66 & 1.30 \\
\hline Mortality & 4.60 & 5.00 & 3.00 \\
\hline $\begin{array}{l}\text { Recruitment: } \\
\text { Mortality }\end{array}$ & 1.74 & 0.13 & 0.43 \\
\hline
\end{tabular}

of plants over 6 years between 1993-99 were equal or less than the changes in numbers between 1991-1992 at all 3 sites (Figures 3-5). The raw monitoring data results are presented in Appendix D.

Recruitment and mortality calculations, spanning 1991-1999, provide meaning to the pattern in total numbers. Mortality and recruitment were generally low at all sites throughout the period except for high recruitment at Grove Creek in 1991-92 and high mortality at Mystery Cave Ridge in 1991-92 (Table 2). The average recruitment values at Grove Creek are on an order of magnitude greater than at Mystery Cave Ridge (Table 3).

The low degree of change in mortality and recruitment over the 6-year interval as compared to the annual intervals of monitoring supports the interpretation that mortality and recruitment are epi- sodic. The low mortality rates indicate that Shoshonea pulvinata is a long-lived perennial of typically stable numbers, consistent with its cushion-plant growth form.

There are similar levels of mortality in each transect, but recruitment levels vary between transects by an order of magnitude (Table 3 ). The ratios between recruitment and mortality thus differ by similar magnitudes.

Low recruitment can be due to low seed production, low germination, or predation. As a step in evaluating seed production, we examined flower production tallies (Table 4). Flower production data indicates that Mystery Cave Ridge transect flowering levels are several times higher than either of the other 2 transects in terms of total number of inflorescences and mean number of inflorescences per plant. Seedlings were absent from Mystery

\begin{tabular}{|l|c|c|c|c|c|c|}
\hline \multicolumn{6}{|c|}{ Table 4. Mean flower production of Shoshonea pulvinata } \\
\hline & \multicolumn{2}{|c|}{ Grove Creek } & \multicolumn{2}{c|}{ Mystery Cave Ridge } & \multicolumn{2}{c|}{ Mys tery Cave Road } \\
\cline { 2 - 7 } & $\begin{array}{l}\text { Total no. of } \\
\text { inflorescences }\end{array}$ & $\begin{array}{l}\text { Mean no. } \\
\text { inflor/plant }\end{array}$ & $\begin{array}{l}\text { Total no. of } \\
\text { inflorescences }\end{array}$ & $\begin{array}{l}\text { Mean no. } \\
\text { inflor/plant }\end{array}$ & $\begin{array}{l}\text { Total no. of } \\
\text { inflorescences }\end{array}$ & $\begin{array}{l}\text { Mean no. } \\
\text { inflor/plant }\end{array}$ \\
\hline \hline $\mathbf{1 9 9 1}$ & 97 & 6 & 366 & 17.4 & 209 & 6.3 \\
\hline $\mathbf{1 9 9 2}$ & 37 & 3.7 & 158 & 12.5 & 44 & 3.1 \\
\hline $\mathbf{1 9 9 3}$ & 93 & 6.2 & 329 & 20.5 & 114 & 3.7 \\
\hline
\end{tabular}

\begin{tabular}{|l|r|r|r|}
\hline \multicolumn{3}{|c|}{ Table 5. Meas ures of viability bas ed on population growth and elas ticity } \\
\hline & $\begin{array}{c}\text { Grove } \\
\text { Creek }\end{array}$ & $\begin{array}{c}\text { Mys tery Cave } \\
\text { Ridge }\end{array}$ & $\begin{array}{c}\text { Mys tery Cave } \\
\text { Road }\end{array}$ \\
\hline \hline $\begin{array}{l}\text { Slope of linear regression (est. } \\
\text { of growth rate ) }\end{array}$ & 1.898405 & -0.06518 & -0.01598 \\
\hline $\begin{array}{l}\text { Rate of change in the mean } \\
\text { (est. of elas ticity) }\end{array}$ & 4.456574 & 0.04032 & 0.001256 \\
\hline
\end{tabular}


Cave Ridge, unlike the other sites, despite the high mean flower production levels. We can rule out low seed production as the cause for low recruitment at Mystery Cave Ridge unless explained by such factors as the preponderance of staminate flowers among inflorescences, low seed set, or the high levels of flower abortion per inflorescence.

Linear regressions were calculated to determine that increase of the Grove Creek sample population is significant, while the decreases of the Mystery Cave sample populations are not significant (Table 5; $\mathrm{P}=0.05$ ). This analysis is customarily used with 8-9 years of census data to accommodate for stochasticity (Dennis et al. 1991). While the environment of Shoshonea pulvinata fluctuates greatly over time, the numbers of plants did not fluctuate between any monitoring interval. Thus, this tool serves in this case for preliminary trend analysis.

Finally, we re-examined the data on net plant surface area (Figures 6-8). It shows that Mystery Cave Ridge is the only sample set with plants that have increased in surface area. Plants at Mystery Cave Road, the shaded site, decreased in surface area.
While many plants grew larger over the 19911993 interval at all 3 sites, only the Mystery Cave Ridge plants continued that trend in 1993-1999 (Table 6). Note that the table below represents only those plants present throughout the 9-year monitoring interval, omitting plants that died or were newly established in the course of the monitoring. The linear regression calculations that represent the net change in surface area among persisting plants document the significance of Mystery Cave Ridge increase, but neither of the decreases at the other two sites are statistically significant (Table 7; $\mathrm{P}=0.05$.)

According to the 1991-93 monitoring surveys Shoshonea pulvinata populations appeared to be healthy and stable. The 1993 data analysis focused on evaluation of plant surface area, a measure of growth, as reflected in the numbers of plants that increased, decreased, or remained the same. In 1999, only the number of plants that increased in plant size at Mystery Cave Ridge is statistically significant. But long-term trends are difficult to detect over a short time span for a slow-growing perennial, and the added 6 year monitoring interval represented an extension of previous patterns. The surface area change (increase or decrease) of most plants was 0-12 $\mathrm{cm} \leq$ over the nine year period. Many of the very

\begin{tabular}{|c|c|c|c|c|c|c|c|c|}
\hline \multicolumn{9}{|c|}{ Table 6. Tally of Shoshonea pulvinata plant size changes } \\
\hline & \multicolumn{4}{|c|}{1991 ñ 1993 size comparis on } & \multicolumn{4}{|c|}{1993 - 1999 size comparis on } \\
\hline & Same & Larger & Smaller & Total & Same & Larger & Smaller & Total \\
\hline Grove Creek & 19 & 24 & 10 & 53 & 35 & 15 & 11 & 61 \\
\hline Mystery Cave Ridge & 5 & 12 & 4 & 21 & 5 & 10 & 4 & 19 \\
\hline Mystery Cave Road & 9 & 21 & 16 & 46 & 10 & 14 & 19 & 43 \\
\hline
\end{tabular}

\begin{tabular}{|l|c|c|c|}
\hline \multicolumn{1}{|l|}{$\begin{array}{l}\text { Table 7. Meas ures of plant surface area trends bas ed on } \\
\text { population growth and elas ticity }\end{array}$} \\
\hline & $\begin{array}{c}\text { Grove } \\
\text { Creek }\end{array}$ & $\begin{array}{c}\text { Mystery Cave } \\
\text { Ridge }\end{array}$ & $\begin{array}{c}\text { Mys tery Cave } \\
\text { Road }\end{array}$ \\
\hline \hline $\begin{array}{l}\text { Slope of linear } \\
\text { regression (est. of } \\
\text { growth rate ) }\end{array}$ & -0.0035 & 1.171583 & -0.02798 \\
\hline $\begin{array}{l}\text { Rate of change in } \\
\text { the mean (est. of } \\
\text { elas ticity) }\end{array}$ & 0.000963 & 18.76083 & 0.001199 \\
\hline
\end{tabular}


Figure 6

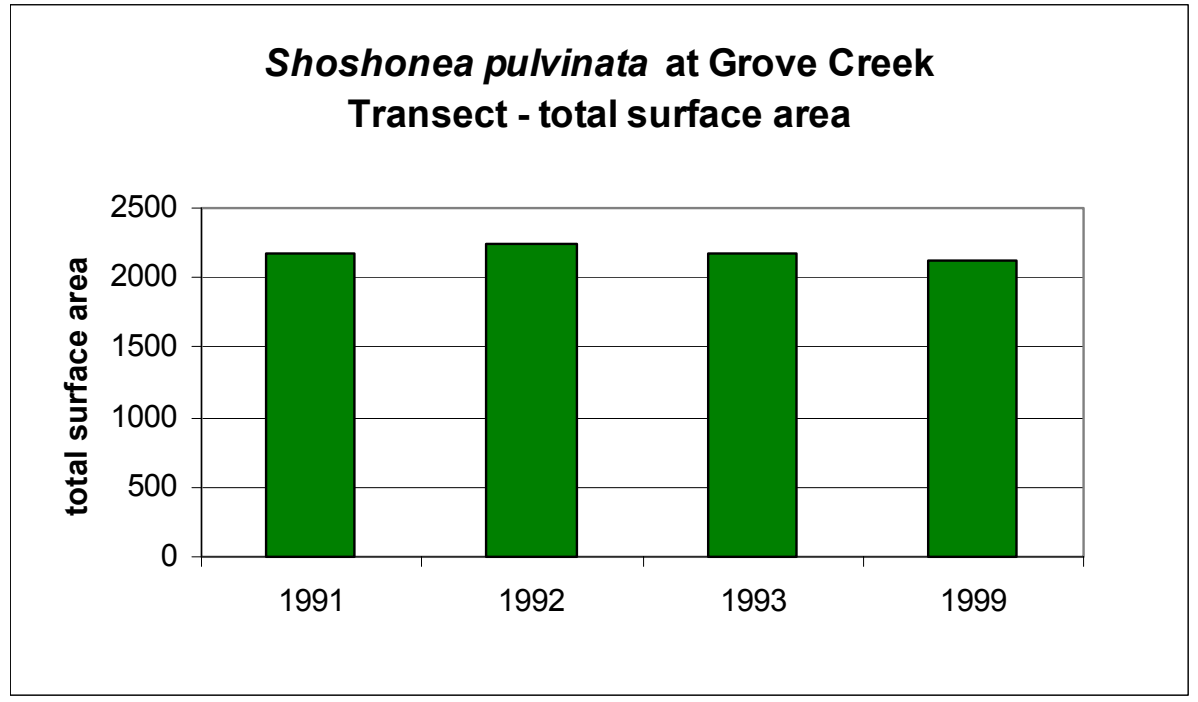

Figure 7

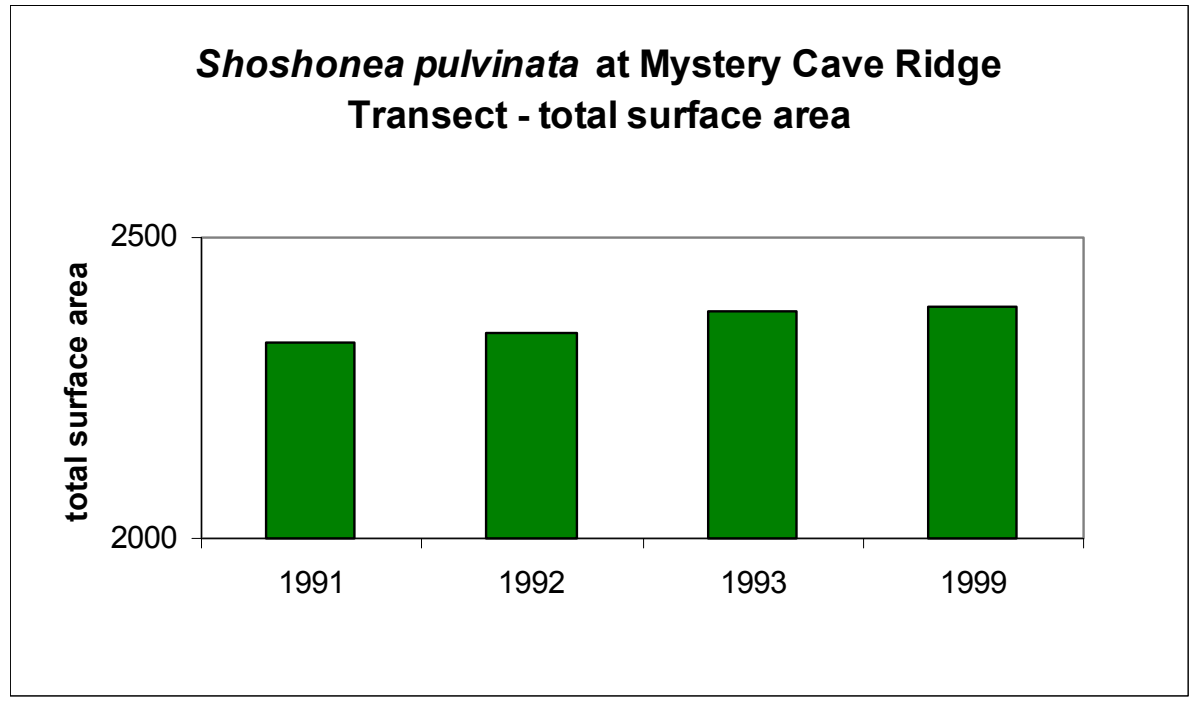

Figure 8

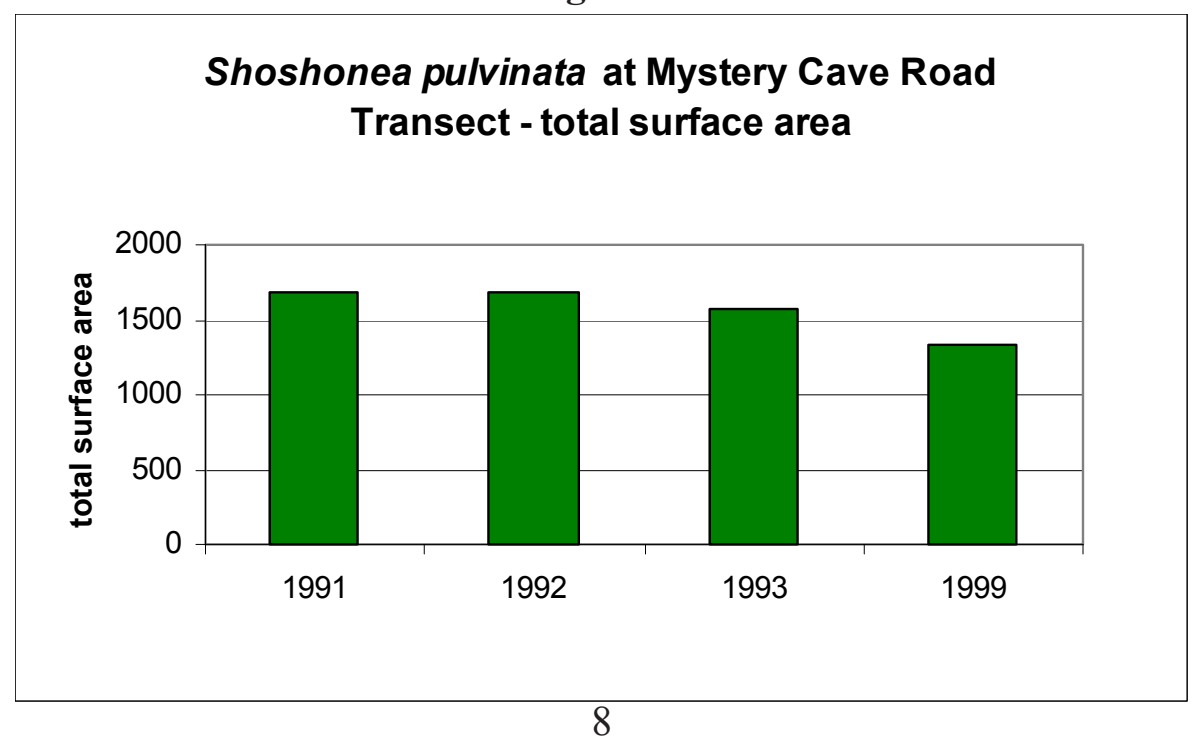


smallest plants $(4 \mathrm{~cm} \leq)$ in 1991 were the same size in 1999. The maximum growth of $80 \mathrm{~cm} \leq$ over 9 years was held by the largest plant among all plots, which began at $488 \mathrm{~cm} \leq$. If it had grown in the past at this same rate, it would be over 50 years old, a very conservative estimate. We also looked at change in net surface area of plants that were present throughout the monitoring period. Anet decline in Shoshonea pulvinata canopy cover for Mystery Cave Road is indicated (Figure 8). This could be due to shading effects.

\section{Discussion}

\section{Life History Considerations}

Critical life history transitions and rates contrast at the 3 sites. The seed germination stage appears to be the critical life history transition for Shoshonea pulvinata at Mystery Cave Ridge, which had the greatest decline. The Mystery Cave Ridge transect is comprised of large, expanding plants that flower prolifically, but seedling germination is uncommon. It has the lowest recruitment rate and seedlings were absent in 1999 unlike the other 2 transects. This setting is the most exposed of the 3 , and appears to be a place where plants are old. It also has the highest mortality of the 3 transects, compounding the affects of low germination. The mortality values were highest in 1992, even though the 1991-92 annual and growing season precipitation levels were at or above mean precipitation levels as indicated by the nearest station in Lovell, WY. Mortality was not selective; the plants that died, that in 1992 ranged from $4 \tilde{n} 28 \mathrm{~cm} \leq$; skewed toward the large end of the range. Both flowering and nonflowering plants died. All mortality was concentrated in half of the transect, and 2 contiguous frames had 100\% mortality. The habitat does not vary much across the length of the transect, so the concentrated mortality points to a localized mortality factor. Without knowing the cause, we do not know its chance for recurrence. We did not see signs of herbivory in 1999. There was a rust present on the leaves of a few plants, but there was no apparent affect at the time of monitoring.

The seedling recruitment stage also appears to be the critical life history transition at Mystery Cave Road. While the decline in numbers is not as steep as the other Mystery Cave transect, the affects of low recruitment may be compounded by accompanying declines in plant vigor (surface area) over time. Possible explanations for decline in vigor include the increases in shade or the increase in Douglas-fir needle litter over time. The decreasing vigor of Mystery Cave Road plants corroborates observations made by Lesica and Shelly (1988) that plants in shaded habitat appeared to be less vigorous than those in full or nearly full sunlight.

Fecundity is perhaps the limiting factor at the Grove Creek sample population. Of all the study sites, Grove Creek had the highest recruitment and is comprised of higher densities of smaller plants, possibility indicating a younger population age structure.

The data on life history transitions and rates provides more meaningful trend data than measurements of plant size.

\section{$\underline{\text { Management Recommendations }}$}

The study results point to the importance of species longevity and recruitment. We recommend that a priority be placed on avoiding impacts from management actions or developments.

We note that there is a high concentration of regional endemic plant species in the Pryor Mountains area (Lesica and Achuff 1992, Heidel and Fertig 2000), with habitat overlap between 2 of the rarest, Shoshonea pulvinata and Lesquerella lesicii. They overlap with other tracked species 
and potential species of concern. In addition, their habitats represent high-elevation phases of unique cushion plant communities. Significant populations of all 3 lie within the East Pryor Mountains ACEC, recently established. Based on results of this study, avoiding impacts to Shoshonea pulvinata is integral to speciesí conservation.

It is appropriate that the fire management policy and any related vegetation management address these species as protection targets, in collaboration with Bighorn Canyon NRA, to maintain early- to mid-successional conditions on suitable ridge settings without destabilizing the habitat. The work of identifying timber and fire management objectives on the East Front of the Pryor Mountains would ideally include a monitoring study of Shoshonea pulvinata response to litter removal, canopy opening, and prescribed burn.

We do not have data or observations that will support or refute the need for evaluating the affects of wild horses and bighorn sheep on Shoshonea pulvinata. No direct evidence of grazing was observed. The effects of horse trampling on lower-elevation cushion plant communities have been identified as warranting further evaluation in Bighorn Canyon NRA (Heidel and Fertig 2000). We recommend presenting the monitoring study results to wildlife biologists familiar with horse and sheep use patterns for advice on how these patterns overlap with distribution and habitat of Shoshonea pulvinata, and to identify any additional Shoshonea pulvinata monitoring needs.

It would be interesting, but not a management imperative, to conduct a one-day examination of seed production factors at Mystery Cave Ridge. This entails documenting staminate vs. perfect flowers, fruit abortion, and fruit viability. If seed production is ruled out, this points to seed germination as the critical life history stage. Rimrock subpopulations that are in naturally harsh settings for seed germination may have different viability than other subpopulations.

In the absence of any intervening management actions, we recommend revisiting the 3 transects within 8-10 years in an ongoing gauge of trend over time. 


\section{Literature Cited}

Dennis, T., P. L. Munholland, and J. Michael Scott. 1991. Estimation of growth and extinction parameters for endangered species. Ecol. Monog. 61:115-143.

Evert, E. F. and L. Constance. 1982. Shoshonea pulvinata, a new genus and species of Umbelliferae from Wyoming. Systematic Botany 7: 471-475.

Fertig, W., C. Refsdahl, and J. Whipple. 1994. Wyoming Rare Plant Field Guide. Wyoming Rare Plant Technical Committee, Cheyenne, WY.

Heidel, B. and W. Fertig. 2000. Rare plants of Bighorn Canyon National Recreation Area. Report to the National Fish and Wildlife Foundation and Bighorn Canyon National Receration Area. Montana Natural Heritage Program and Wyoming Natural Diversity Database.

Lesica, P. 1987. A technique for monitoring nonrhizomatous, perennial plant species in permanent belt transect. Nat. Areas J. 7:65-68.

Lesica, P. 1992. Monitoring populations of Shoshonea pulvinata in the Pryor and Beartooth mountains, Carbon County, Montana, 1992 progress report. Unpublished report to the Bureau of Land Management. Montana Natural Heritage Program, Helena.

Lesica, P. 1993. Monitoring populations of Shoshonea pulvinata in the Pryor and Beartooth mountains, Carbon County, Montana, 1991-93 baseline report. Unpublished report to the Bureau of Land Management. Montana Natural Heritage Program, Helena.
Lesica, P. and P. L. Achuff. 1991. Monitoring populations of Shoshonea pulvinata in the Pryor and Beartooth mountains, Carbon County, Montana, 1991 establishment report. Unpublished report to the Bureau of Land Management. Montana Natural Heritage Program, Helena.

Lesica, P. and P. L. Achuff. 1992. Distribution of vascular plant species of special concern and limited distribution in the Pryor Mountain Desert, Carbon County, MT. Montana Natural Heritage Program, Helena.

Lesica, P. and J. S. Shelly. 1988. Report on the conservation status of Shoshonea pulvinata, a candidate threatened species. Report to the U.S. Fish and Wildlife Service, Office of Endangered Species, Denver, Colorado.

Menges, E. S. and D. R. Gordon. 1996. Three levels of monitoring intensity for rare plant species. Nat. Areas J. 16(3): 227-237.

Morris, W., D. Doak, M. Groom, P. Kareiva, J. Fieberg, L. Gerber, P. Murphy, and D. Thomson. 1999. A practical handbook for population viability analysis. The Nature Conservancy.

Sokal and Rohlf. 1981. Biometry. W.H. Freeman and Co., New York, NY.

USDI Bureau of Land Management. 1996. Montana State Office special status plant species. BLM Manual 6840.

USDI Fish and Wildlife Service. 1993. Endan gered and threatened wildlife and plants: Review of plant taxa for listing as endan gered or threatened species; Notice of review. Federal Register 58(188): 5114451190. 


\section{Appendix A}

Study area photographs

Grove Creek

photo by Steve Shelley

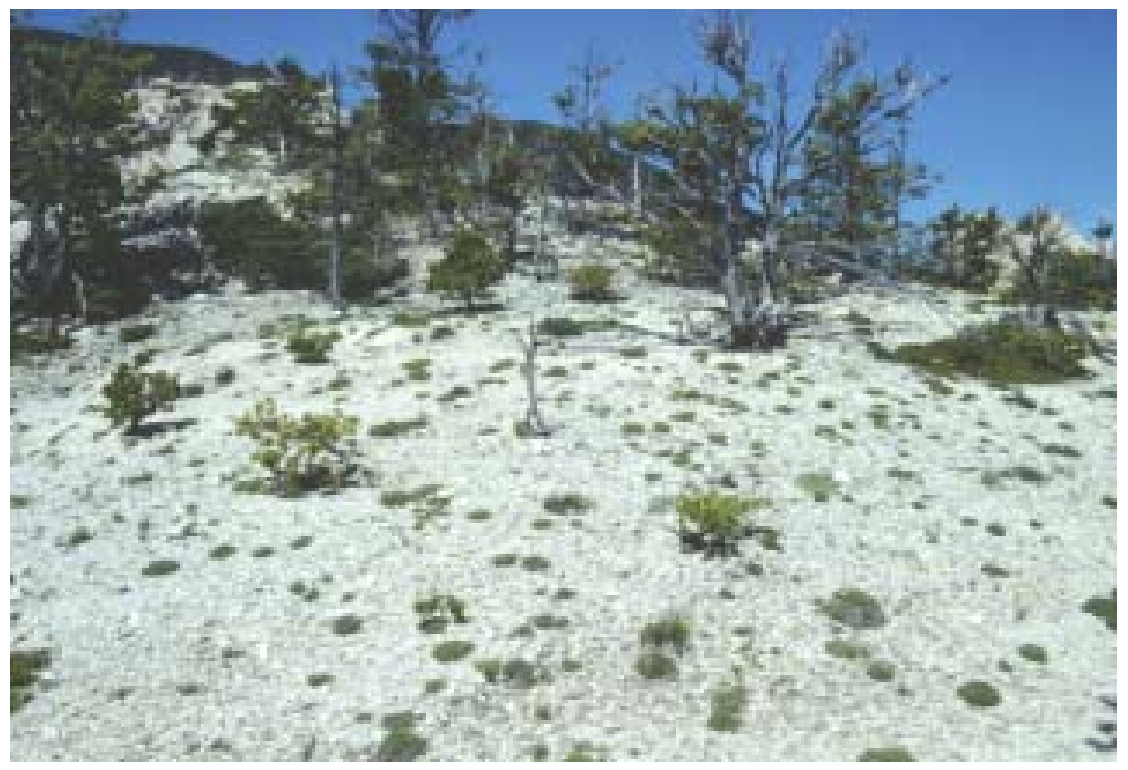

Mystery Cave Ridge

photo by Bonnie Heidel

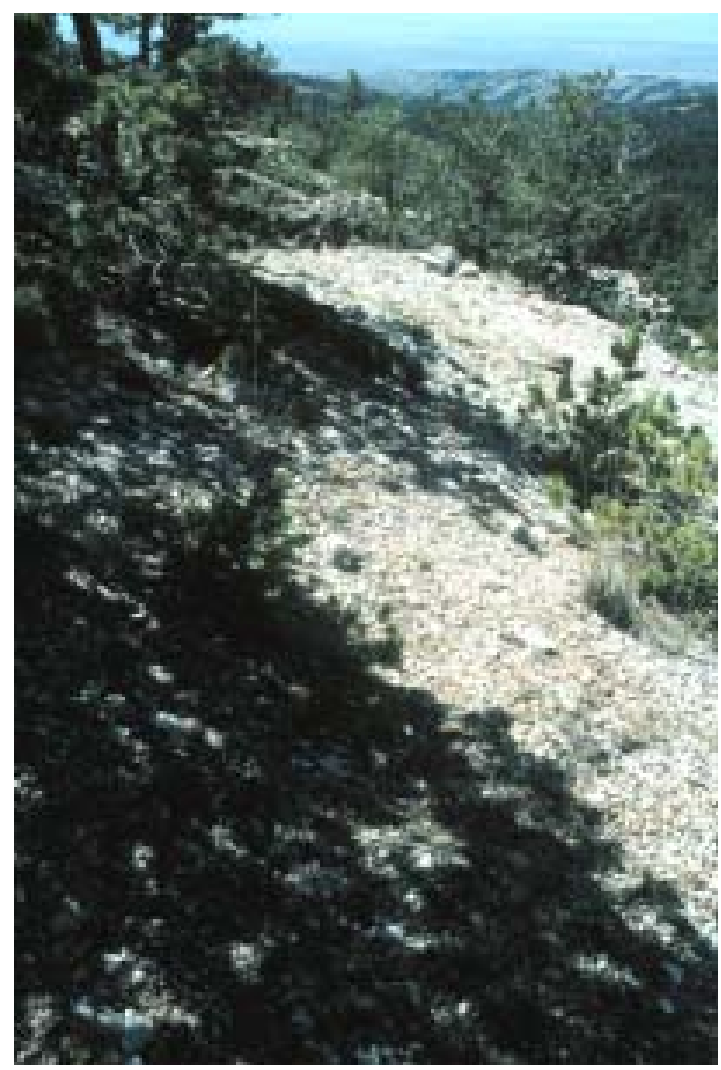

Mystery Cave Road

photo by Bonnie Heidel

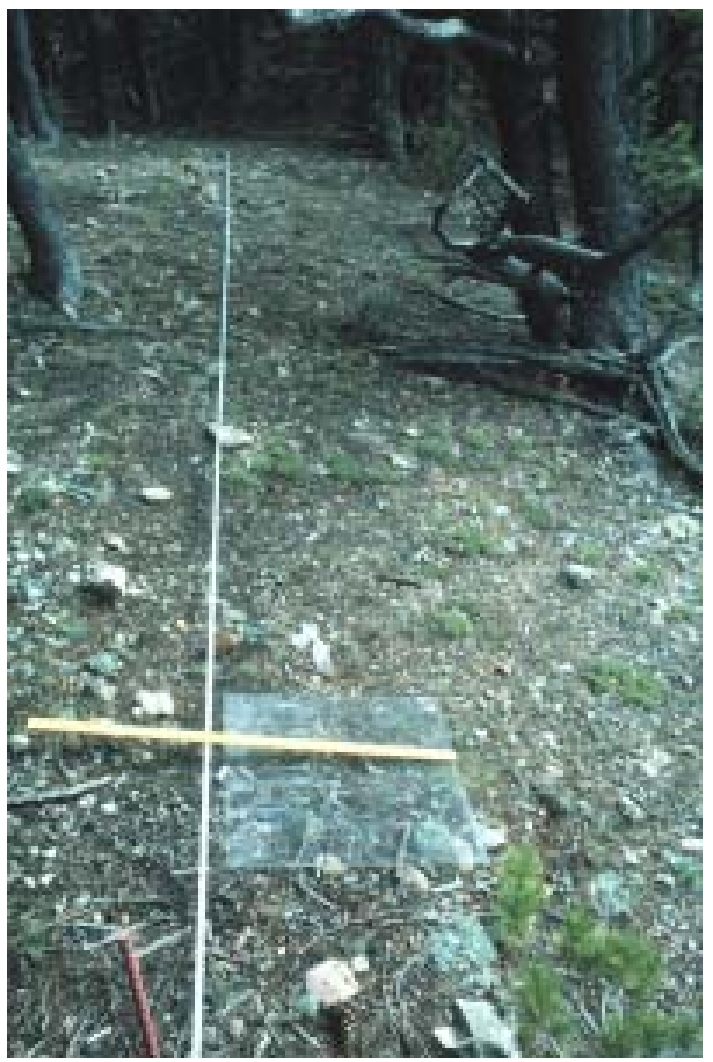




\section{Appendix B}

Climate of Lovell, Wyoming

This diagram shows average monthly temperatures and precipitation.

Growing season length is the number of frost-free days, ie., with mean

daily minimum temperatures above zero degrees centigrade.

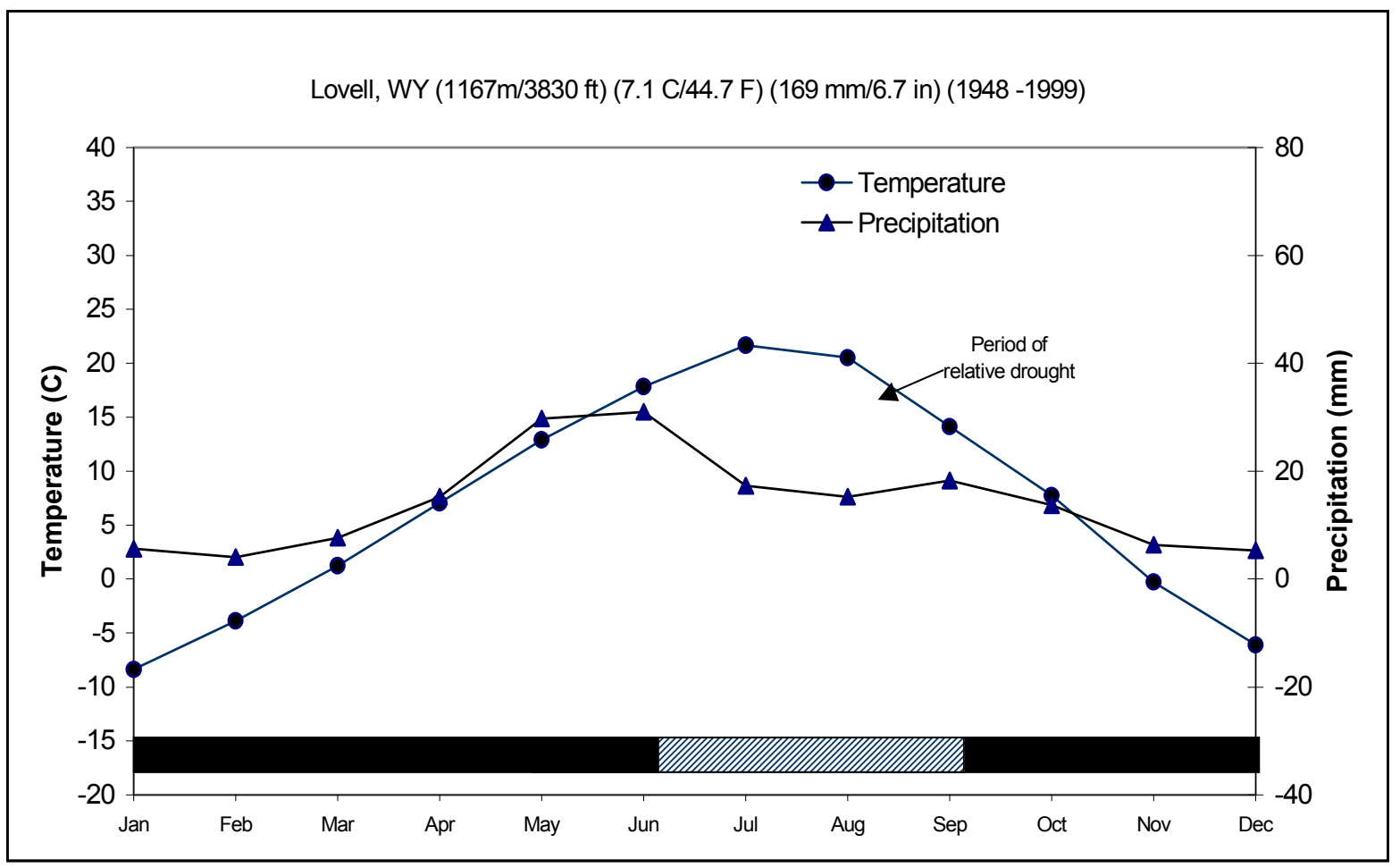




\section{Appendix C}

Mean monthly precipitation and temperature in Lovell, Wyoming

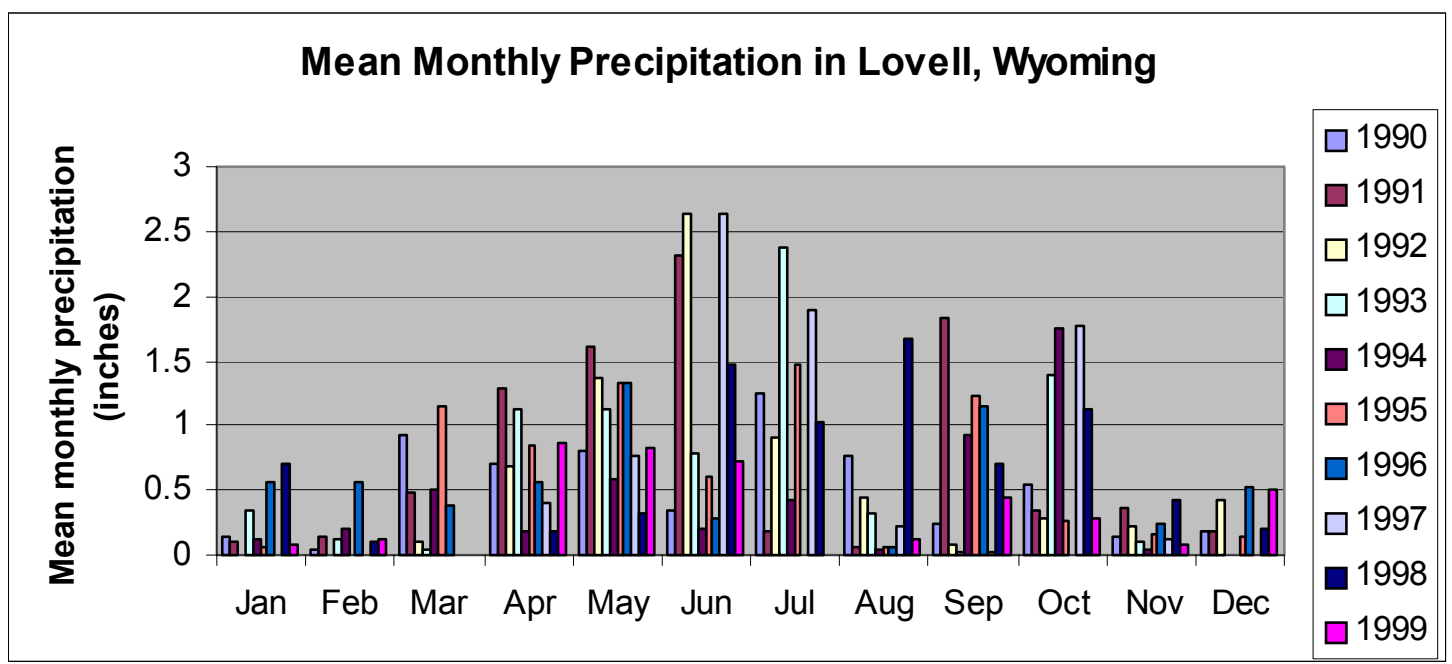

\section{Mean Monthly Temperature in Lovell, Wyoming}

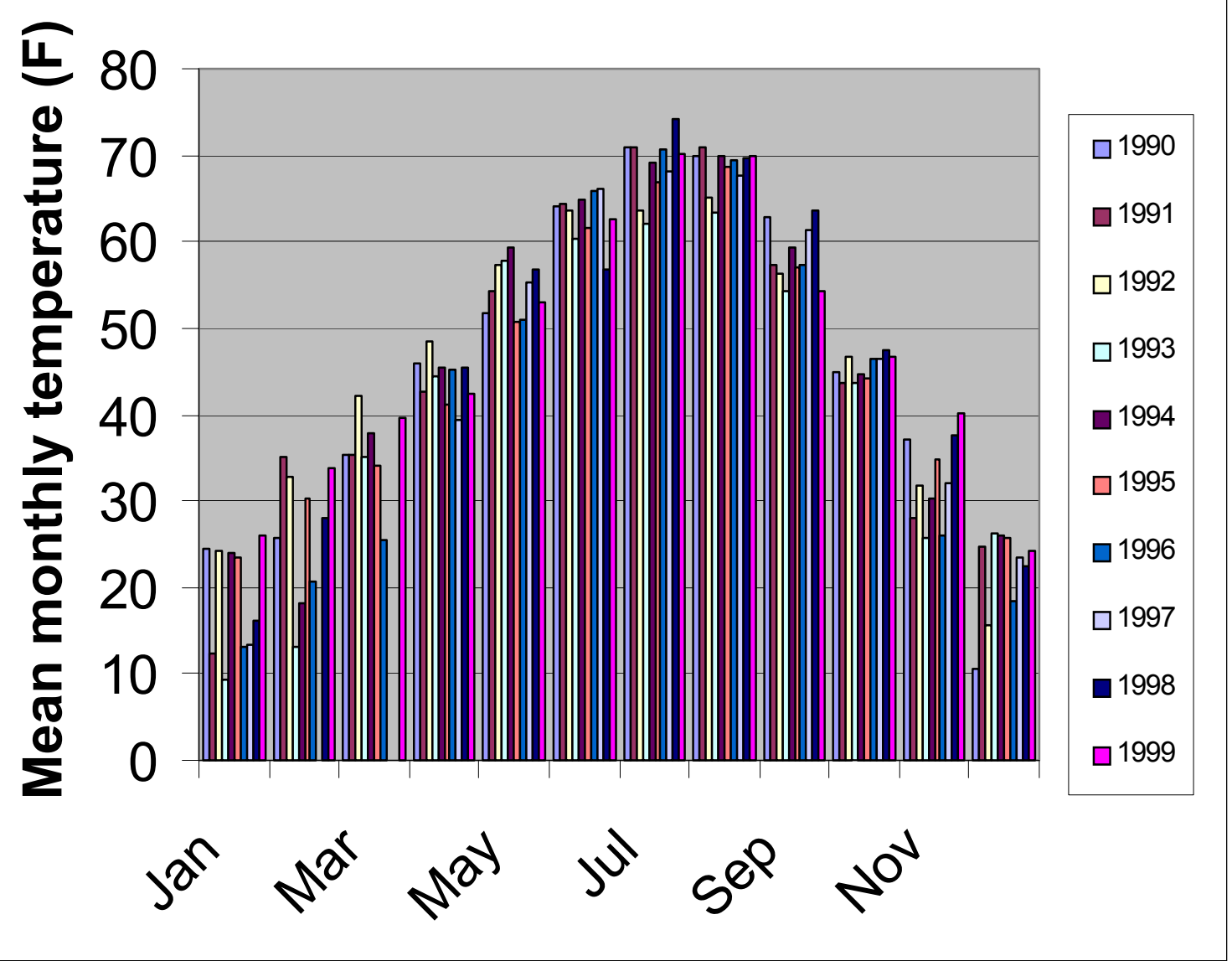




\section{Appendix D}

Shoshonea pulvinata raw monitoring data

\begin{tabular}{|c|c|c|c|c|}
\hline & \multicolumn{3}{|c|}{ Grove Creek } & \\
\hline & 1991 & 1992 & 1993 & 1999 \\
\hline $1 a$ & A144-10 & A128-10 & A116-10 & A100-17 \\
\hline $\mathrm{b}$ & A4-10 & A4-10 & A4-10 & A4-10 \\
\hline $\mathrm{C}$ & A16-10 & A12-10 & A16-10 & A24-11 \\
\hline$d$ & A8-10 & A8-10 & A8-10 & A12-11 \\
\hline $\mathrm{e}$ & A4-10 & A4-10 & A4-10 & A4-10 \\
\hline$f$ & A16-10 & A16-10 & A16-10 & A20-10 \\
\hline $\mathrm{g}$ & -- & A4-10 & A4-10 & -- \\
\hline $\mathrm{h}$ & -- & A4-10 & A4-10 & -- \\
\hline$T$ & -- & -- & -- & A4-10 \\
\hline $2 a$ & A4-10 & A4-10 & A4-10 & A8-10 \\
\hline $\mathrm{b}$ & A4-10 & A4-10 & -- & -- \\
\hline $\mathrm{C}$ & A4-10 & A4-10 & A4-10 & A4-10 \\
\hline $\mathrm{d}$ & A4-10 & A4-10 & A4-10 & A4-10 \\
\hline $\mathrm{e}$ & A228-16 & A240-11 & A208-10 & A180-15 \\
\hline$f$ & A4-10 & A4-10 & A4-10 & A4-10 \\
\hline $\mathrm{g}$ & A40-15 & A44-10 & A48-12 & A44-11 \\
\hline $\mathrm{h}$ & A28-12 & A28-10 & A36-10 & A32-15 \\
\hline $\mathrm{i}$ & A16-I1 & A16-10 & A16-10 & A20-11 \\
\hline$j$ & A4-10 & A8-10 & A8-10 & A8-11 \\
\hline $\mathrm{k}$ & A4-10 & A4-10 & A4-11 & A4-10 \\
\hline I & -- & A4-10 & -- & -- \\
\hline $\mathrm{m}$ & -- & A4-10 & A4-11 & A4-10 \\
\hline $\mathrm{n}$ & -- & $\mid--$ & -- & A0-10 seedling \\
\hline 0 & -- & -- & -- & A0-10 seedling \\
\hline$p$ & -- & -- & -- & A4-10 \\
\hline $3 a$ & A4-10 & A4-10 & A8-10 & A8-10 \\
\hline $\mathrm{b}$ & A20-10 & A28-10 & A24-10 & A24-13 \\
\hline $\mathrm{C}$ & A36-13 & A40-12 & A28-11 & A32-14 \\
\hline$d$ & A4-10 & A8-10 & A16-10 & A12-10 \\
\hline $\mathrm{e}$ & -- & -- & -- & A0-10 seedling \\
\hline $4 a$ & A8-10 & A4-10 & A4-10 & A4-10 \\
\hline $\mathrm{b}$ & A4-10 & -- & -- & -- \\
\hline $\mathrm{C}$ & A4-10 & -- & - & -- \\
\hline $\mathrm{d}$ & A4-10 & A8-10 & A8-11 & A8-10 \\
\hline $\mathrm{e}$ & A20-11 & A16-10 & A12-10 & A12-14 \\
\hline$f$ & A4-10 & A4-10 & -- & -- \\
\hline $\mathrm{g}$ & A4-10 & |- & - & -- \\
\hline $\mathrm{h}$ & A4-10 & A4-10 & -- & -- \\
\hline $\mathrm{i}$ & A104-12 & A108-11 & A112-17 & A104-114 \\
\hline $\mathrm{j}$ & A4-10 & A4-10 & A4-10 & A4-10 \\
\hline $\bar{k}$ & -- & A4-10 & A8-10 & A8-11 \\
\hline$T$ & -- & A4-10 & A4-10 & A8-10 \\
\hline $\mathrm{m}$ & -- & A4-10 & A4-10 & A4-10 \\
\hline $\mathrm{n}$ & -- & A4-10 & A4-10 & -- \\
\hline 0 & -- & A4-10 & A4-10 & A4-10 \\
\hline$p$ & -- & A4-10 & -- & -- \\
\hline$q$ & -- & A4-10 & -- & -- \\
\hline$r$ & -- & -- & A4-10 & A12-11 \\
\hline $\mathrm{t}$ & -- & -- & -- & A0-10 seedling \\
\hline $\mathrm{u}$ & -- & -- & -- & A4-10 \\
\hline
\end{tabular}

\begin{tabular}{|c|c|c|c|c|}
\hline & \multicolumn{3}{|c|}{ Grove Creek } & \multirow[b]{2}{*}{1999} \\
\hline & 1991 & 1992 & 1993 & \\
\hline $\mathrm{v}$ & -- & -- & -- & A4-10 \\
\hline $5 a$ & A40-11 & A76-14 & A64-10 & A32-12 \\
\hline $\mathrm{b}$ & A64-17 & A64-13 & A60-17 & A52-18 \\
\hline $\mathrm{C}$ & A8-10 & A12-10 & A12-10 & A12-I1 \\
\hline $6 a$ & A116-I11 & A108-13 & A120-I11 & A100-I15 \\
\hline $\mathrm{b}$ & A68-112 & $\mathrm{A} 60-13$ & A56-17 & A52-116 \\
\hline $\mathrm{C}$ & A16-10 & A16-12 & A20-13 & A16-I3 \\
\hline $\mathrm{d}$ & A80-15 & A84-12 & A88-14 & A80-19 \\
\hline $\mathrm{e}$ & A108-17 & A112-11 & A112-14 & A92-113 \\
\hline$f$ & A4-10 & A4-10 & A8-10 & A8-10 \\
\hline $\mathrm{g}$ & A4-10 & A4-10 & A4-10 & -- \\
\hline $\mathrm{h}$ & A4-10 & A8-10 & A12-10 & A12-I0 \\
\hline $\mathrm{i}$ & A4-10 & A4-10 & A4-10 & A4-10 \\
\hline $\mathrm{j}$ & -- & A4-10 & A4-10 & A4-10 \\
\hline $\mathrm{k}$ & -- & -- & A4-10 & A4-10 \\
\hline$T$ & -- & -- & A4-10 & -- \\
\hline $\mathrm{m}$ & -- & -- & -- & A0-10 seedling \\
\hline $\mathrm{n}$ & -- & -- & -- & A0-10 seedling \\
\hline $7 a$ & A24-10 & A28-10 & A20-10 & A20-10 \\
\hline $\mathrm{b}$ & A12-10 & A12-10 & A12-10 & A16-10 \\
\hline $\mathrm{c}$ & A16-10 & A16-10 & A20-10 & A20-10 \\
\hline $8 a$ & A112-10 & A120-10 & A120-10 & A100-14 \\
\hline $\mathrm{b}$ & A116-14 & A132-10 & A100-110 & A128-19 \\
\hline $\mathrm{C}$ & -- & -- & -- & A0-10 seedling \\
\hline d -- & -- & -- & -- & A0-10 seedling \\
\hline $\bar{e}$ & -- & -- & -- & A0-10 seedling \\
\hline$f$ & -- & -- & -- & A0-10 seedling \\
\hline $9 a$ & A52-10 & A60-10 & A52-15 & A60-13 \\
\hline $\mathrm{b}$ & A20-10 & A28-10 & A24-10 & A16-I1 \\
\hline $\mathrm{c}$ & A16-10 & A16-10 & A20-10 & A16-10 \\
\hline d & -- & A4-10 & A4-10 & A4-10 \\
\hline $10 a$ & A532-127 & A500-115 & A492-129 & \begin{tabular}{|l|} 
A552-147 \\
\end{tabular} \\
\hline $\mathrm{b}$ & A4-10 & A4-10 & A8-10 & A8-10 \\
\hline c & A16-I3 & A20-10 & A20-10 & A24-17 \\
\hline $\mathrm{d}$ & A4-10 & A4-10 & A8-10 & A8-11 \\
\hline $\mathrm{e}$ & A4-10 & A4-10 & A4-10 & A4-10 \\
\hline$f$ & A4-10 & A4-10 & A4-10 & A4-10 \\
\hline $\mathrm{g}$ & -- & A4-10 & A4-10 & A4-10 \\
\hline $\mathrm{h}$ & -- & -- & A4-10 & A4-10 \\
\hline $\mathrm{i}$ & -- & -- & A4-10 & A4-10 \\
\hline j & -- & -- & -- & A0-10 seedling \\
\hline $\mathrm{k}$ & -- & -- & -- & A0-10 seedling \\
\hline 1 & -- & -- & -- & A0-10 seedling \\
\hline size total & 2176 & 2244 & 2176 & 2116 \\
\hline total A-20 & 14 & 15 & 21 & 23 \\
\hline total 20- & 17 & 19 & 18 & 19 \\
\hline total & 57 & 68 & 66 & 67 \\
\hline Inflor & 97 & 37 & 93 & 188 \\
\hline Fl. & 16 & 10 & 15 & 29 \\
\hline Veg & 15 & 24 & 24 & 13 \\
\hline total A4 & 26 & 34 & 27 & 25 \\
\hline
\end{tabular}




\begin{tabular}{|c|c|c|c|c|}
\hline & \multicolumn{3}{|c|}{ Mystery Cave Ridge } & \multirow[b]{2}{*}{1999} \\
\hline & 1991 & 1992 & 1993 & \\
\hline $1 a$ & A116-I20 & A108-16 & A128-I22 & A144-I32 \\
\hline $\mathrm{b}$ & A196-I12 & A220-10 & A224-I15 & A 184-I17 \\
\hline $\mathrm{c}$ & A348-124 & A352-14 & A348-123 & A308-119 \\
\hline \multicolumn{5}{|l|}{$\mathrm{d}$ out } \\
\hline $2 a$ & A20-10 & -- & -- & -- \\
\hline $\mathrm{b}$ & A244-143 & A244-I26 & A244-139 & A188-145 \\
\hline$c, d$ & A488-127 & A520-19 & A524- 150 & A568-148 \\
\hline $\mathrm{e}$ & A 16-11 & -- & -- & -- \\
\hline$f$ & A44-I31 & A48-13 & A36-I11 & -- \\
\hline $3 a$ & A80-120 & A84-I15 & --- & -- \\
\hline $\mathrm{b}$ & A16-14 & -- & -- & -- \\
\hline $\mathrm{c}$ & -- & A4-10 & -- & -- \\
\hline $4 a$ & A16-14 & -- & -- & -- \\
\hline $\mathrm{b}$ & A28-19 & -- & -- & -- \\
\hline $5 a$ & A 16-15 & -- & -- & -- \\
\hline $\mathrm{b}$ & A 16-I3 & -- & -- & -- \\
\hline $\mathrm{c}$ & A14-10 & -- & -- & -- \\
\hline$d$ & A4-10 & -- & -- & -- \\
\hline $\mathrm{e}$ & -- & -- & A4-10 & A8-10 \\
\hline $6 a$ & A56-10 & A52-15 & A60-I1 & -- \\
\hline $\mathrm{b}$ & A64-I11 & A84-12 & A72-14 & A52-13 \\
\hline $\mathrm{C}$ & A28-10 & A28-10 & A20-13 & -- \\
\hline$d$ & A16-I0 & -- & -- & -- \\
\hline $7 a$ & A16-10 & A12-10 & A16-10 & A16-10 \\
\hline $\mathrm{b}$ & A32-12 & A44-10 & A44-13 & A56-17 \\
\hline $\mathrm{C}$ & A16-10 & A24-10 & A20-10 & A20-12 \\
\hline$d$ & A24-10 & A32-10 & A24-10 & A28-10 \\
\hline $8 a$ & A 128-I23 & A120-I19 & A148-I38 & A 156-I35 \\
\hline$b$ & A88-I11 & A88-19 & A96-I12 & A 108-I20 \\
\hline $9 a$ & A16-10 & A8-10 & A8-10 & A8-10 \\
\hline $\mathrm{b}$ & A16-I0 & A4-10 & A4-10 & A4-10 \\
\hline $\mathrm{c}$ & A160-I34 & A204-132 & A 192-159 & A208-144 \\
\hline$d$ & A48-I11 & A56-18 & A56-17 & A68-18 \\
\hline $10 a$ & A236-169 & A188-I21 & A 192-I51 & A220-182 \\
\hline $11 a$ & A32-12 & A32-10 & A36-I1 & A32-14 \\
\hline size total & 2324 & 2340 & 2376 & 2386 \\
\hline total 8-20 & 11 & 2 & 4 & 4 \\
\hline total 20- & 19 & 19 & 16 & 14 \\
\hline total & 32 & 23 & 22 & 19 \\
\hline Inflor & 366 & 158 & 329 & 366 \\
\hline $\mathrm{Fl}$. & 21 & 13 & 16 & 14 \\
\hline Veg & 9 & 8 & 4 & 4 \\
\hline total A4 & 2 & 2 & 2 & 1 \\
\hline
\end{tabular}




\begin{tabular}{|c|c|c|c|c|}
\hline & \multicolumn{3}{|c|}{ Mystery Cave Road } & \multirow[b]{2}{*}{1999} \\
\hline & 1991 & 1992 & 1993 & \\
\hline $3 a$ & A48-12 & A52-10 & A36-14 & A60-15 \\
\hline$b$ & A76-16 & A44-13 & A48-14 & A48-13 \\
\hline c & A48-11 & A44-10 & A28-16 & A44-I1 \\
\hline d & A20-12 & A32-10 & A32-18 & A28-13 \\
\hline $\mathrm{e}$ & A16-10 & -- & -- & -- \\
\hline$f$ & A52-11 & A76-10 & A68-13 & A20-10 \\
\hline $\mathrm{g}$ & A24-11 & A16-10 & A26-11 & A36-13 \\
\hline $\mathrm{h}$ & A16-11 & A16-10 & A20-11 & A16-10 \\
\hline$i$ & A24-10 & A24-10 & A24-10 & A20-10 \\
\hline j & A16-10 & A8-10 & A8-11 & A8-10 \\
\hline $\mathrm{k}$ & A16-I1 & A8-10 & A12-11 & A12-10 \\
\hline 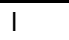 & A4-10 & -- & - & -- \\
\hline $\mathrm{m}$ & A32-10 & A24-10 & A32-10 & A24-10 \\
\hline $\mathrm{n}$ & A24-12 & A32-10 & A36-13 & A28-13 \\
\hline 0 & A56-14 & A16-10 & A28-11 & A24-13 \\
\hline$p$ & A16-11 & A8-10 & A16-11 & A16-10 \\
\hline$q$ & & not in & & \\
\hline r -- & -- & -- & - & A0-10 seedling \\
\hline s -- & -- & -- & - & A0-10 ì \\
\hline$t$ & -- & -- & -- & A0-10 ì \\
\hline u -- & -- & -- & -- & A0-10 ì \\
\hline V -- & -- & -- & -- & A0-10 ì \\
\hline $4 a$ & A52-10 & A40-10 & A52-10 & A40-15 \\
\hline $\mathrm{b}$ & A20-12 & A16-10 & A20-12 & A12-10 \\
\hline c & A16-10 & -- & - & -- \\
\hline$d$ & A40-13 & A48-10 & A44-10 & A44-17 \\
\hline $\mathrm{e}$ & A16-10 & -- & -- & -- \\
\hline$f$ & A24-15 & A32-10 & A28-11 & A20-11 \\
\hline $\mathrm{g}$ & A64-11 & A36-11 & A24-I1 & A32-11 \\
\hline $\mathrm{h}$ & -- & -- & A4-10 & -- \\
\hline $\mathrm{i}$ & -- & -- & -- & A8-10 \\
\hline j & -- & -- & - & A0-10 seedling \\
\hline $\mathrm{k}$ & -- & -- & - & A0-10 seedling \\
\hline $5 a$ & A56-14 & A68-11 & A60-18 & -- \\
\hline $\mathrm{b}$ & A60-10 & A60-12 & A68-14 & A12-10 \\
\hline $\mathrm{c}$ & A96-11 & A96-10 & A96-I11 & A80-12 \\
\hline$d$ & A132-I20 & A140-18 & A140-I1 & A96-113 \\
\hline $\mathrm{e}$ & -- & -- & - & A0-10 seedling \\
\hline
\end{tabular}

\begin{tabular}{|c|c|c|c|c|}
\hline & \multicolumn{3}{|c|}{ Mystery Cave Road } & \multirow[b]{2}{*}{1999} \\
\hline & 1991 & 1992 & 1993 & \\
\hline $6 a$ & A80-17 & A84-14 & A72-13 & A64-16 \\
\hline $7 a$ & A24-12 & A28-I1 & A28-I1 & A56-16 \\
\hline $\mathrm{b}$ & A24-12 & A40-12 & A32-I1 & A 12-10 (merged w/ 8c) \\
\hline $8 a$ & A80-I11 & A96-I11 & A88-I14 & A72-19 \\
\hline $\mathrm{b}$ & A36-15 & A44-13 & A40-11 & A40-I1 \\
\hline $\mathrm{c}$ & A64-I12 & A56-13 & A56-11 & (above) \\
\hline $\mathrm{d}$ & A20-10 & A24-10 & A24-10 & -- \\
\hline $\mathrm{e}$ & A16-10 & A24-11 & A32-12 & A24-10 \\
\hline$f$ & -- & -- & -- & A0-10 seedling \\
\hline $11 a$ & A20-10 & A20-10 & A20-10 & A24-10 \\
\hline $\mathrm{b}$ & A40-12 & A44-10 & A28-19 & A40-I12 \\
\hline $\mathrm{C}$ & A24-11 & A28-10 & A32-I1 & A24-I2 \\
\hline $\mathrm{d}$ & A36-I1 & A32-10 & A40-10 & A28-10 \\
\hline $\mathrm{e}$ & A16-10 & A8-10 & A8-10 & A12-10 \\
\hline $12 a$ & A64-14 & A64-10 & A24-10 & A32-13 \\
\hline $\mathrm{b}$ & A64-10 & A48-10 & A48-14 & A60-15 \\
\hline $\mathrm{C}$ & A48-11 & A48-13 & A44- 15 & A40-I12 \\
\hline $\mathrm{d}$ & A24-10 & A16-I1 & A20-10 & A20-I1 \\
\hline $\mathrm{e}$ & A44-13 & A32-10 & A36-I10 & A24-15 \\
\hline$f$ & A4-10 & A4-10 & A4-10 & -- \\
\hline $\mathrm{g}$ & A4-10 & A4-10 & A4-10 & A8-10 \\
\hline $\mathrm{h}$ & A4-10 & A4-10 & A8-10 & A12-10 \\
\hline $\mathrm{i}$ & A4-10 & A8-10 & A8-10 & A12-10 \\
\hline \begin{tabular}{|l}
$j$ \\
\end{tabular} & A4-10 & A 12-10 & A12-10 & A16-I2 \\
\hline $\mathrm{k}$ & -- & A4- 10 & -- & -- \\
\hline 1 & -- & -- & -- & A4-10 \\
\hline $\mathrm{m}$ & -- & -- & -- & A0-10 seedling \\
\hline $\mathrm{n}--$ & -- & -- & -- & A0-10 seedling \\
\hline size total & 1676 & 1676 & 1566 & 1340 \\
\hline total 8-20 & 13 & 12 & 11 & 17 \\
\hline total 20- & 31 & 31 & 33 & 26 \\
\hline total & 50 & 47 & 47 & 44 \\
\hline Inflor & 209 & 44 & 114 & 113 \\
\hline $\mathrm{Fl}$. & 33 & 14 & 31 & 25 \\
\hline Veg & 11 & 29 & 13 & 18 \\
\hline total A4 & 6 & 4 & 3 & 1 \\
\hline
\end{tabular}




\section{Appendix E}

Global and State Rank Guidelines

The term ìspecies of special concernî includes taxa that are rare, endemic, disjunct, threatened or endangered throughout their range or in Montana, vulnerable to extirpation from Montana, or in need of further research. The term also encompasses species that have a special designation by organizations or land management agencies in Montana, including: Bureau of Land Management Special Status and Watch species; U.S. Forest Service Sensitive and Watch species; U.S. Fish and Wildlife Service Threatened, Endangered and Candidate species.

Taxa are evaluated and ranked by the Heritage Program on the basis of their global (range-wide) status, and their statewide status according to a standardized procedure used by all Natural Heritage Programs. These ranks are used to determine protection and data collection priorities, and are revised as new information becomes available.

For each level of distributionóglobal and stateóspecies are assigned a numeric rank ranging from 1 (critically imperiled) to 5 (demonstrably secure). This reflects the speciesí relative endangerment and is based primarily on the number of occurrences of that species globally or within the state. However, other information such as date of collection, degree of habitat threat, geographic distribution patterns and population size and trends is considered when assigning a rank, and the number of occurrences listed below are suggestions, not absolute criteria.

For example, Clustered ladyís slipper (Cypripedium fasciculatum) is ranked G4 S2. That is, globally the species is apparently secure, while in Montana it is imperiled because of rarity, or because of other factors making it demonstrably vulnerable to extirpation.

For ranks, substitute S (State) or G (Global) in these definitions

\begin{tabular}{|l|l|}
\hline Rank & Definition \\
\hline $\mathbf{1}$ & $\begin{array}{l}\text { Critically Imperiledó Critically imperiled because of extreme rarity or because of some } \\
\text { factor(s) making it especially vulnerable to extirpation. Typically } 5 \text { or fewer occurrences or } \\
\text { very few remaining individuals }(<1,000) .\end{array}$ \\
\hline $\mathbf{2}$ & $\begin{array}{l}\text { Imperiledó Imperiled because of rarity or because of some factor(s) making it very } \\
\text { vulnerable to extirpation. Typically } 6 \text { to } 20 \text { occurrences or few remaining individuals }(1,000 \\
\text { to } 3,000) .\end{array}$ \\
\hline $\mathbf{3}$ & $\begin{array}{l}\text { Vulnerableó Vulnerable either because rare and uncommon, or found only in a restricted } \\
\text { range (even if abundant at some locations), or because of other factors making it vulnerable } \\
\text { to extirpation. Typically } 21 \text { to } 100 \text { occurrences or between 3,000 and } 10,000 \text { individuals. }\end{array}$ \\
\hline $\mathbf{4}$ & $\begin{array}{l}\text { Apparently Secureó Uncommon but not rare, and usually widespread. Possible cause of } \\
\text { long-term concern. Usually more than } 100 \text { occurrences and more than } 10,000 \text { individuals. }\end{array}$ \\
\hline $\mathbf{5}$ & $\begin{array}{l}\text { Secureó Common, widespread, and abundant. Essentially ineradicable under present } \\
\text { conditions. Typically with considerably more than } 100 \text { occurrences and more than } 10,000 \\
\text { individuals. }\end{array}$ \\
\hline
\end{tabular}


**Qualifiers and Rank Ranges**

\begin{tabular}{|c|c|}
\hline Qualifier & Definition \\
\hline \#\# & $\begin{array}{l}\text { Range Rankó A numeric range rank (e.g., S2S3) is used to indicate the range of } \\
\text { uncertainty about the exact status of the element. Ranges cannot skip more than one rank } \\
\text { (e.g., SU is used rather than S1S4). }\end{array}$ \\
\hline$?$ & Unrankedó rank not yet assessed. \\
\hline \# & $\begin{array}{l}\text { A modifier to } \mathrm{X} \text { or } \mathrm{H} \text {; the species has been reintroduced but the population is not yet } \\
\text { established. }\end{array}$ \\
\hline * & $\begin{array}{l}\mathrm{G} \text { or } \mathrm{S} \text { rank has been assigned and is under review. Contact the individual state Natural } \\
\text { Heritage program for assigned rank. }\end{array}$ \\
\hline HYB & Hybridó Element not ranked because it represents an interspecific hybrid, not a species. \\
\hline $\mathbf{U}$ & $\begin{array}{l}\text { Unrankableó Currently unrankable due to lack of information or due to substantially } \\
\text { conflicting information about status or trends. }\end{array}$ \\
\hline $\mathbf{E}$ & $\begin{array}{l}\text { Exoticó An established exotic; may be native in nearby regions (e.g., house finch or catalpa } \\
\text { in eastern U.S.). }\end{array}$ \\
\hline E\# & $\begin{array}{l}\text { Exotic Numericó An established exotic that has been assigned a numeric rank to indicate } \\
\text { its status, as defined for G1 or S1 through G5 or S5. }\end{array}$ \\
\hline A & $\begin{array}{l}\text { Accidentaló Accidental or casual, in other words, infrequent and outside usual range. } \\
\text { Includes species (usually birds or butterflies) recorded once or only a few times at a } \\
\text { location. A few of these species may have bred on the one or two occasions they were } \\
\text { recorded. Examples include European strays or western birds on the East Coast and vice- } \\
\text { versa. }\end{array}$ \\
\hline B & Breedingó Basic rank refers to the breeding population of the element. \\
\hline $\mathbf{C}$ & Captive or Cultivatedó Native element presently extant only in captivity or cultivation. \\
\hline$\overline{\mathbf{H}}$ & $\begin{array}{l}\text { Possibly Extirpated (Historical)ó Element occurred historically, and there is some } \\
\text { expectation that it may be rediscovered. Its presence may not have been verified in the past } \\
20 \text { years. An element would become GH or SH without such a } 20 \text {-year delay if the only } \\
\text { known occurrences were destroyed or if it had been extensively and unsuccessfully looked } \\
\text { for. Upon verification of an extant occurrence, GH or SH-ranked elements would typically } \\
\text { receive a G1 or S1 rank. The GH or SH rank should be reserved for elements for which } \\
\text { some effort has been made to relocate occurrences, rather than simply using this rank for all } \\
\text { elements not known from verified extant occurrences. }\end{array}$ \\
\hline $\mathbf{N}$ & Nonbreedingó Basic rank refers to the non-breeding population of the element. \\
\hline $\mathbf{P}$ & Potentialó Potential that element occurs but no extant or historic occurrences are accepted. \\
\hline $\mathbf{R}$ & $\begin{array}{l}\text { Reportedó Element reported but without a basis for either accepting or rejecting the report, } \\
\text { or the report not yet reviewed locally. Some of these are very recent discoveries for which } \\
\text { the program hasn't yet received first-hand information; others are old, obscure reports. }\end{array}$ \\
\hline $\mathbf{T}$ & $\begin{array}{l}\text { Rank for subspecific taxon (subspecies, variety, or population); appended to the global rank } \\
\text { for the full species, e.g. G4T3 }\end{array}$ \\
\hline $\mathbf{X}$ & $\begin{array}{l}\text { Presumed Extirpatedó Element is believed to be extirpated. Not located despite intensive } \\
\text { searches of historical sites and other appropriate habitat, and virtually no likelihood that it } \\
\text { will be rediscovered. }\end{array}$ \\
\hline
\end{tabular}




\section{CRITERIA USED FOR RANKING}

The criteria for ranking are based on a set of quantitative and qualitative factors. These factors are listed below in order of their general importance:

a. Number of Element Occurrences (EOs):

the estimated number of EOs throughout the Elementís global range;

b. Abundance:

the estimated global abundance of the Element (measured by number of individuals, or area, or stream length covered);

c. Size of Range:

the estimated size of the Elementís global range;

d. Distribution trend:

the trend in the Elementís distribution over its global range;

e. Number of protected EOs:

the estimated number of adequately protected EOs throughout the Elementís global range;

f. Degree of threat:

the degree to which the Element is threatened globally;

g. Fragility:

the fragility or susceptibility of the Element to intrusion;

h. Other global considerations:

for example, the quality or condition of EOs that affect or may affect endangerment status; unexplained population fluctuations; reproductive strategies that are dependent on specific habitat; etc. 